\title{
VESICO-URETERIC REFLUX IN PARAPLEGIA: RESULTS OF VARIOUS FORMS OF MANAGEMENT
}

\author{
By Edward Tarabulcy, M.D., ${ }^{1}$ Pablo A. Morales, M.D., \\ and James F. Sullivan, M.D.
}

The Department of Urology and the Institute of Rehabilitation Medicine, New York, University Medical Center, New York, N.Y., and The New York State Rehabilitation Hospital, West Haverstraw, N.Y.

VESICO-URETERIC reflux is one of the main causes of loss of renal function in the paraplegic. The purpose of this retrospective study was to evaluate the various forms of management of reflux.

\section{CLINICAL MATERIAL}

This consisted of Ioo refluxing ureters in 68 patients with acquired paraplegia, and 37 refluxing ureters in 25 congenital (spina bifida) paraplegics, encountered at the Department of Urology and the Institute of Rehabilitation Medicine, New York University Medical Center, New York, N.Y., and the New York State Rehabilitation Hospital, West Haverstraw, N.Y., over a period of $13 \frac{1}{2}$ years.

\section{DURATION OF FOLLOW-UP}

\section{Acquired group:}

68 ureters $>2$ years; 32 ureters $<2$ years

Of the above 68 ureters, 32 ureters were followed for more than 5 years. Longest follow-up: I $1 \frac{1}{2}$ years

\section{Congenital group:}

30 ureters $>2$ years; 7 ureters $<2$ years

Of the above 30 ureters, 24 ureters were followed for more than 5 years. Longest follow-up: $13 \frac{1}{2}$ years.

\section{METHODS OF TREATMENT}

I. Scheduled voiding at least 2-3 hourly, during waking hours.

2. Continuous bladder drainage.

3. T.U.R. of the vesical neck.

4. Anti-reflux operation.

5. Ileal conduit.

We are conservative in our approach to reflux in the paraplegic; we go down the above list only when we have to, and only as far as we have to.

${ }^{1}$ Present address: Department of Urology, The Geisinger Medical Center, Danville, Pennsylvania I782I, U.S.A. 
ACQUIRED GROUP:

\section{RESULTS}

\begin{tabular}{|c|c|c|c|c|}
\hline & \multicolumn{3}{|c|}{$\begin{array}{c}\text { SuCCEss } \\
\text { (Regression of reflux) }\end{array}$} & \multirow[t]{2}{*}{ FAILURE } \\
\hline & Complete & Partial & Total & \\
\hline SCHEDULED VOIDING & 19 & I & 20 & Io \\
\hline $\begin{array}{l}\text { CoNTINUOUS DRAINAGE } \\
\text { Urethral catheter } \\
\text { Cystostomy } \\
\text { Vesicostomy }\end{array}$ & $\begin{array}{r}35 \\
5 \\
-\end{array}$ & $\frac{8}{-}$ & $\begin{array}{r}43 \\
5 \\
-\end{array}$ & $\begin{array}{r}26 \\
9 \\
2\end{array}$ \\
\hline T.U.R. of Vesical Neck & 8 & - & 8 & 2 \\
\hline $\begin{array}{l}\text { ANTI-REFLUX OPERATION } \\
\text { Uretero-vesicoplasty (Hutch I) } \\
\text { Ureteric advancement (Hutch II) } \\
\text { Uretero-ostioplasty (Bischoff) } \\
\text { Ureteric re-implantation } \\
\text { (Politano-Leadbetter) }\end{array}$ & $\frac{6}{-}$ & $\begin{array}{l}- \\
- \\
-\end{array}$ & $\left.\begin{array}{c}6 \\
- \\
2\end{array}\right\} 8$ & $\left.\begin{array}{l}5 \\
1 \\
2 \\
1\end{array}\right\} 9$ \\
\hline
\end{tabular}

Thus, the ratios of successes to failures for the various methods of treatment were:

Scheduled voiding

Urethral catheter drainage

$20: 10$

Suprapubic cystotomy

$43: 26$

Vesicostomy

T.U.R. of vesical neck

$5: 9$

$0: 2$

Uretero-vesicoplasty (Hutch I)

$8: 2$

Ureteric advancement (Hutch II)

$6: 5$

Uretero-ostioplasty (Bischoff)

$0: \mathrm{I}$

Ureteric re-implantation (Politano-Leadbetter)

$0: 2$

2: I

Congenital Group:

\begin{tabular}{|c|c|c|c|c|}
\hline & \multicolumn{3}{|c|}{$\begin{array}{c}\text { SUCCESS } \\
\text { (Regression of reflux) }\end{array}$} & \multirow[t]{2}{*}{ FAILURE } \\
\hline & Complete & Partial & Total & \\
\hline SCHEDULED VOIDING & I2 & 2 & I4 & 7 \\
\hline $\begin{array}{l}\text { ConTINUOUS DRAINAGE } \\
\text { Urethral catheter } \\
\text { Cystostomy }\end{array}$ & $\begin{array}{l}5 \\
\text { I }\end{array}$ & $\frac{3}{2}$ & $\begin{array}{l}8 \\
\mathbf{I}\end{array}$ & $\begin{array}{r}10 \\
3\end{array}$ \\
\hline $\begin{array}{l}\text { ANTI-REFLUX OPERATION } \\
\text { Uretero-vesicoplasty (Hutch I) }\end{array}$ & 3 & - & 3 & - \\
\hline
\end{tabular}


Here, the ratios of successes to failure were:

$\begin{array}{lr}\text { Scheduled voiding } & \text { I } 4: 7 \\ \text { Urethral catheter drainage } & 8: \text { IO } \\ \text { Suprapubic cystostomy } & \text { I }: 3 \\ \text { Uretero-vesicoplasty (Hutch I) } & 3: 0\end{array}$

\section{FINAL OUTCOME}

Having obtained these results, we could have considered this study completed. However, in patients with neurogenic bladders, vesico-ureteric reflux is notorious for being labile: thus, it may subside for some time, only to reappear later on. Therefore, we decided to determine the final outcome of our treatment on the 137 initially refluxing ureters. Then, we went on to assess the final outcome of our treatment on the function of the involved kidneys.

\section{ReFluX IN THE ACQUiRed Group:}

Of the Ioo initially refluxing ureters in this group, 3 required implantation into ileal conduits on our first urologic evaluation, because of advanced upper urinary tract dilatation. In the remaining 97 refluxing ureters, the outcome of treatment has been favourable in 59-with complete regression of reflux in 53, and partial regression in 6 . The outcome was unfavourable in 38 -with persistence of reflux; I 5 of these have required implantation into ileal conduits.

\section{FINDINGS SUMMARISED}

Ioo Refluxing Ureters

3 Initial Ileal Conduits

\section{7}

\begin{tabular}{|c|c|c|c|}
\hline \multicolumn{2}{|c|}{$\begin{array}{c}\text { Favourable Outcome } \\
\text { (Regression of reflux) }\end{array}$} & Unfavourable Outcome \\
\hline Complete & Partial & Total & \\
\hline 53 & 6 & 59 & 38 (15 inileal conduits) \\
\hline
\end{tabular}

Thus:

The outcome was favourable in 59 ureters and unfavourable in 38 -a ratio of approximately $3: 2$. $I$ in 5 .

Of the 100 ureters, 18 required implantation into an ileal conduit-i.e. about 


\section{Reflux in the Congenital Group:}

In the congenital group of 37 initially refluxing ureters, 8 required implantation into ileal conduits at the outset of treatment. In the remaining 29 ureters, the outcome of our management was favourable in 14 -with complete regression of reflux in II, and partial regression in 3. It was unfavourable in 15-with persistence of reflux; 8 of these have had to be implanted into ileal conduits during the course of treatment.

\section{FINDINGS SUMMARISED}

37 Refluxing Ureters

8 Initial Ileal Conduits

29

\begin{tabular}{|c|c|c|c|}
\hline \multicolumn{3}{|c|}{$\begin{array}{l}\text { FAVOURABLE OUTCOME } \\
\text { (Regression of reflux) }\end{array}$} & \multirow[t]{2}{*}{ UNFAVOURABLE OUTCOME } \\
\hline Complete & Partial & Total & \\
\hline I I & 3 & I4 & I5 (8 ileal conduits) \\
\hline
\end{tabular}

Thus:

The outcome was favourable in 14 ureters and unfavourable in $15-$ a ratio of approximately I : I.

Of the 37 ureters, I6 had to be implanted into an ileal conduit-i.e. about 2 out of 5 .

\section{Renal Function in the AcQuired Group:}

In this group, I2 kidneys initially showed impaired renal function. In 6 of these, renal function is improved at the present time; the ureters of 2 are implanted into ileal conduits. Renal function in the remaining 6 has remained impaired; 2 of these have ureters implanted into ileal conduits.

Adequate function was initially noted in 88 kidneys. Of these, 9 now have impaired function; the ureter of one is implanted into an ileal conduit. The remaining 79 are still functioning normally.

\section{Findings SumMarised}

$\begin{array}{cc}\text { INITIALLY IMPAIRED } & \text { I2 kidneys } \\ \text { Results: Improved } & 6 \text { (2 with ileal conduits) } \\ \text { No change } & 6 \text { (2 with ileal conduits) } \\ \text { INITIALLY NoRMAL } & 88 \text { kidneys } \\ \text { Results: Impaired } & 9 \text { (I with ileal conduit) } \\ \text { Unchanged } & 79 \\ \text { Total : } & \text { I00 kidneys }\end{array}$




\section{Renal Function in the Congenital Group:}

Here, 3 kidneys initially had impaired function. At the present time, 2 have not undergone any change and one (now with an ileal conduit) has shown definite improvement.

Of the remaining 34 kidneys (initially functioning normally), 5 have undergone impairment of function; 3 are associated with ileal conduits. The other 29 kidneys still have normal function.

\section{Findings SUMMARISED}

$\begin{array}{rc}\text { INITIALLY IMPAIRED } & 3 \text { kidneys } \\ \text { Results: Improved } & \text { I (with ileal conduit) } \\ \text { No change } & 2 \\ \text { INITIALLY NoRMAL } & 34 \text { kidneys (3 with ileal conduits) } \\ \text { Results: Impaired } & 5 \text { (3 with ileal conduits) } \\ \text { Unchanged } & 29 \\ \text { Total: } & 37 \text { kidneys }\end{array}$

Final Outcome of 32 Ileal Conduits:

\begin{tabular}{|l|c|c|}
\hline & $\begin{array}{c}\text { Acquired } \\
\text { group }\end{array}$ & $\begin{array}{c}\text { Congenital } \\
\text { group }\end{array}$ \\
\hline Post-operative death (shock) & I & - \\
No post-operative follow-up & 4 & 2 \\
Improved upper tract & 3 & I I \\
No change in (dilated)-upper tract & 7 & I \\
$\uparrow$ Dilatation of -upper tract & - & 3 \\
or $\downarrow$ renal function & - & \\
\hline
\end{tabular}

Aside from the patient who died in the immediate post-operative period and the 6 who moved to other parts of the country (and were, therefore, not re-evaluated), we have followed Io patients in the acquired group and 15 in the congenital group.

The upper urinary tracts have improved in 3 of the Io patients in the acquired group; no change was noted in the dilated upper tract of the remaining 7 . The upper urinary tracts have improved in I I of the I 5 patients in the congenital group; no change has been noted in the dilated upper tract of $I$, and worsening of the condition of the upper tracts had been found in the remaining 3 .

\section{CONCLUSION}

We have found that there is no single ideal method of treatment of reflux in the paraplegic: none is consistently or permanently successful. We believe that the choice of a form of treatment depends on the prevailing conditions in the urinary tract. We had originally laid down definite indications for each method; we are still adhering to them today. These indications are:

For Scheduled Voiding: Low residual urine, non-dilated upper urinary tract and adequate renal function. 
For Continuous Bladder Drainage: High residual urine, dilated upper urinary tract or impaired renal function.

For T.U.R. of the Vesical Neck: High residual urine with vesical neck obstruction.

For Anti-reflux Operation: Failed conservative treatment and ureter not grossly dilated.

For Ileal Conduit: (I) Failed conservative treatment and grossly dilated ureter or ureters.

(2) Initially: Advanced upper tract dilatation.

Acknowledgment. We wish to express our appreciation and gratitude to $\mathrm{Mr}$. John Whelan, R.N., Supervisor of Urologic Nursing, Institute of Rehabilitation Medicine, New York University Medical Center, for the highly specialised urological nursing care he has given the patients in this study and for invaluable assistance in the course of preparation of this paper. 